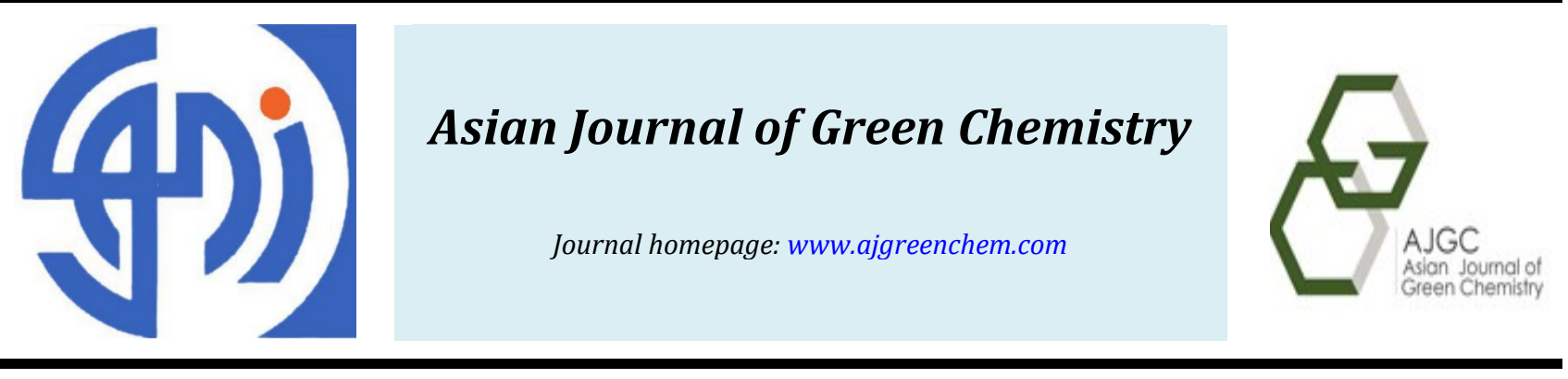

Original Research Article

\title{
Imidazole mediated synthesis of spirooxindoles in water using isatin as a privileged scaffold
}

\author{
Md. Nasim Khana,* (D), Digvijaysinh K. Parmarb, Hardik B. Bhattc \\ a Iqra Pharmaceuticals, Nutanhat, Burdwan, West Bengal-713147, India \\ b Diu College, DHES, Diu (U.T)- 362520, India \\ c Om College of Science, Junagadh-Gujrat-362310, India
}

\section{ARTICLE INFORMATION}

Received: 15 September 2018

Received in revised: 29 October 2018

Accepted: 3 November 2018

Available online: 18 January 2019

DOI: 10.33945/SAMI/AJGC.2019.4.4

\section{KEYWORDS}

\section{Imidazole}

Spirooxindole

Water

Multicomponent reaction

Organocatalysis

\begin{abstract}
This work discusses the synthesis of complex small molecules spirooxindoles using imidazole as an efficient organocatalyst. The three components coupling reactions of isatin, malononitrile, and enolizable 4hydroxycoumarin were performed in water as a green solvent. The reaction was done with imidazole, an amphoteric organocatalyst, to construct the spiro-molecules with high yields. The significant features of this protocol are neutral reaction condition, availability, low cost, metal free, strong acid/base free, and reusable reaction medium with no column chromatography separation. This methodology is useful for the easy access of structurally complex, highly functionalized spirooxindole molecules with the important medicinal chemistry applications.

(C) 2019 by SPC (Sami Publishing Company), Asian Journal of Green Chemistry, Reproduction is permitted for noncommercial purposes.
\end{abstract}

\section{Graphical Abstract}

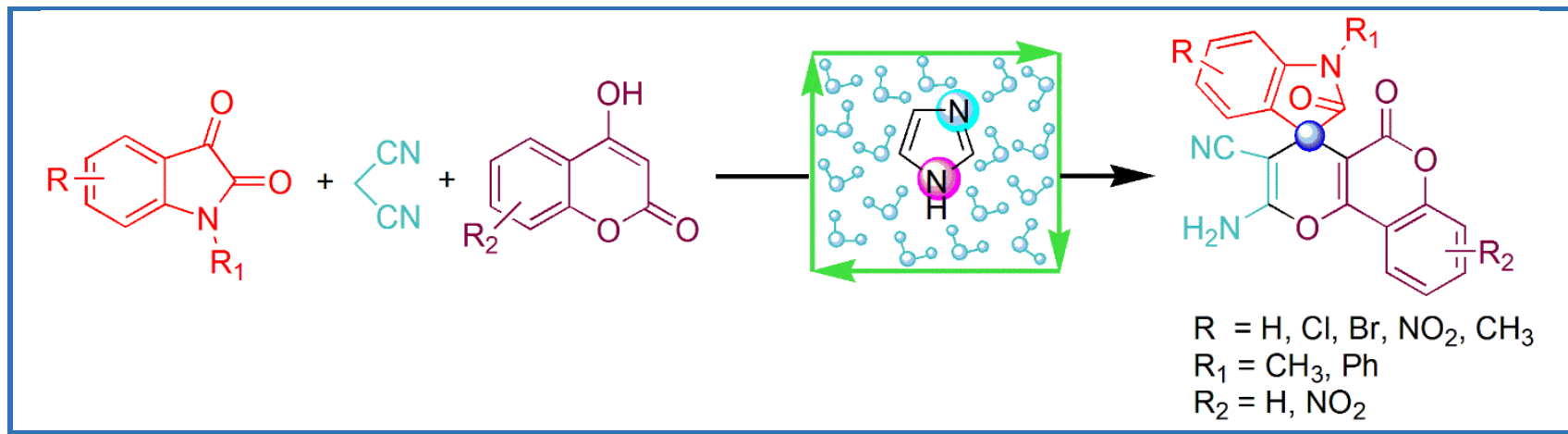

Corresponding author, email: nasimiitp@gmail.com (M.N. Khan).

Tel: +9177 18734311. 


\section{Introduction}

Multicomponent reactions (MCRs) are one of the popular synthetic techniques where more than two substrates react, and have been extensively utilized to obtain simple to complex organic molecules [1-2]. Recently, it has gained significant attention due to its several advantages such as atom, step, and pot economy and are considered as a vital tool in combinatorial chemistry [3] and diversity oriented synthesis [4]. MCRs have played a giant role in synthesis of heterocycles in drug discovery programme [5-6]. Modern organic synthesis construction of the complex heterocycles by MCRs has become an attractive approach [7].

The spirooxindoles are structurally complex natural products and possess some bioactive properties [8-12]. Many naturally obtained spirooxindoles are elacomine, coerulescine, horsfiline, welwitindolinone A, alstonisine, spirotryprostatin A, and surugatoxin. They show potent cytotoxic activity and are known as h5-HT6 serotonin receptors, oxytocin antagonist, estrogen-receptor modulators, and antiproliferative agents [13-15]. Spirooxindoles are promising medicinal molecules in clinical phases $[16,17]$. MK-1602 (Scheme 1, 1) has completed phase-2 clinical trials and reported to treat migraine. Similarly, MI 77301 (Scheme 1, 2), a highly complex spirooxindole, has been reported in phase- 1 clinical trials that may inhibit the interaction of p53 to mouse double minute 2 homolog (MDM2), and a protein-protein interaction [17].

Isatin is one of the most important scaffolds that provides spiro-molecules bearing oxindole moiety [18]. Due to the importance of the spirooxindoles, extensive work has been done for its synthesis. In this direction, we have also explored methods for the synthesis of oxindoles spirofusedpyrans along with the embedded coumarin moiety [19-21]. Literature survey revealed the fact that several synthetic methods have been developed to obtain spirooxindoles attached pyran and coumarin moiety. A three-components condensation is including isatin, malononitrile, and 4hydroxycoumarin [22-41]. Each of the known procedures for the synthesis of corresponding spirooxindoles has its merits; however, further studies are still needed to develop a facile, environmental, and economical multicomponent methodology. To improve yields, most of the reported methods employed nano-particles as heterogeneous catalysts. Although the reports have importance in fundamental research and merit in terms of sustainable chemistry, the issues lie with the reproducibility of morphology and particle sizes [42-44]. To accelerate the organic reactions using small organic molecules, the organocatalysis has played a giant role in organic synthetic transformations. Recently, organocatalysis has gained a great deal of attention in organic synthesis and is one of the important promising area of research [45-47].

Imidazole is one of the organocatalyst and has a very unique reactivity pattern. It has aza (-N=) and amine (-NH-) functionalities in its five membered ring that makes it amphoteric in nature. 
Because of pyridine like, nitrogen atom in the imidazole ring basicity is mild. Due to its mild catalytic nature it may minimize the formation of the side products and improve the yield of the desired compound. Catalytic nature of imidazole has been explored by different groups [48-50].

In continuation of our work to explore the potential of imidazole as organocatalyst in multicomponent reactions (MCRs) [51] we became interested in exploring the imidazole in the synthesis of spirooxindoles. Considering the importance of these molecules, and in continuation of our efforts towards the synthesis of functionalized heterocycles by MCRs, we wanted to explore imidazole to access a complex spiro-heterocycles using in situ generated isatylidene malononitriles derivatives and 4-hydroxycoumarin (Scheme 2). To develop a green and sustainable process for the synthesis of heterocyclic molecules using MCRs, we have developed an efficient method for synthesis of the spirooxindoles embedded with pyrans and coumarin moiety using imidazole as an organocatalyst, and employing water as a green solvent.

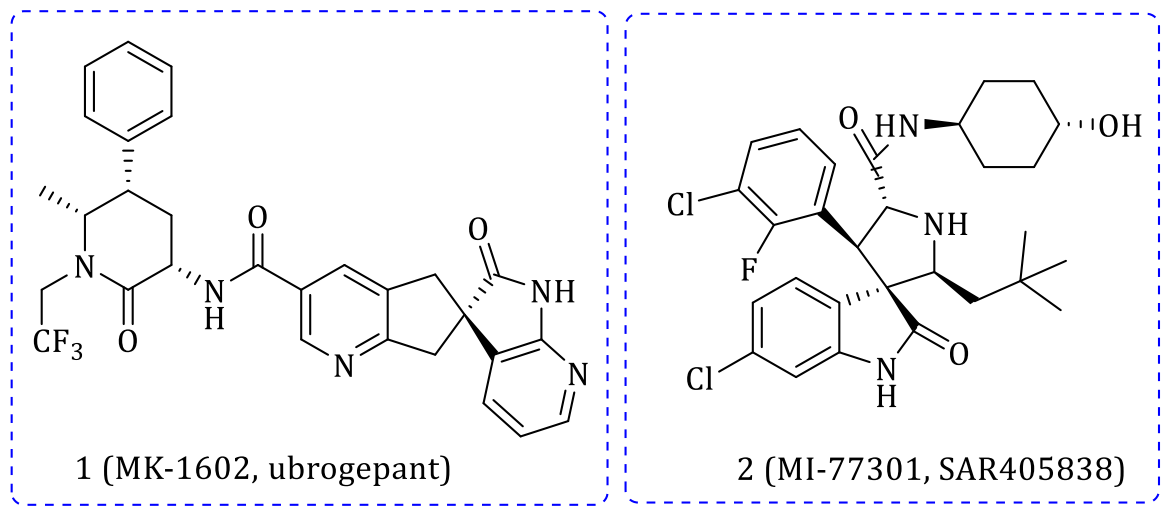

Scheme 1. Spirooxindole molecules in clinical trials.

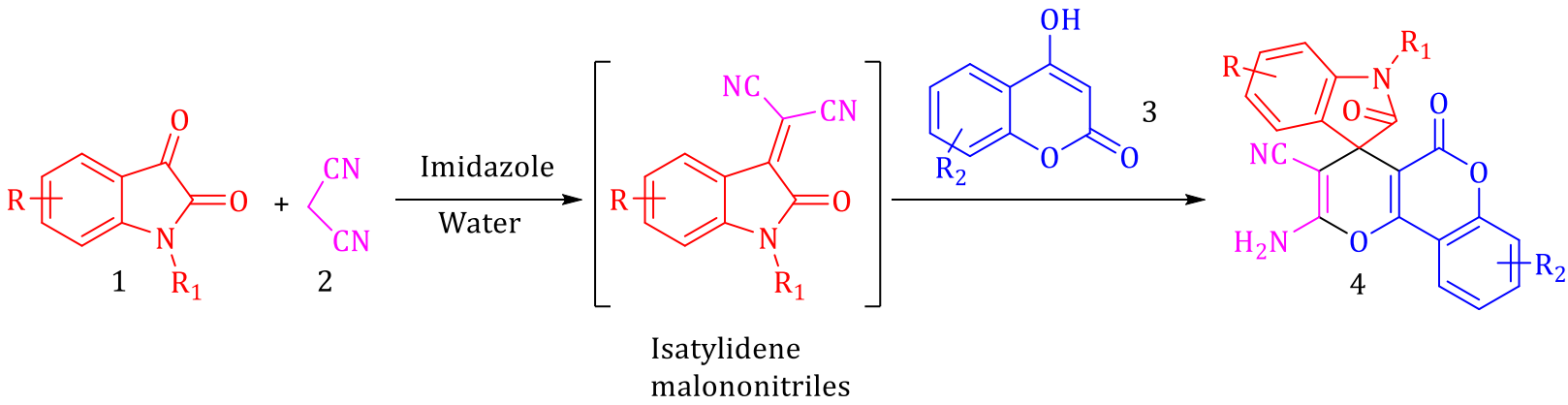

Scheme 2. Three component reaction for the synthesis of spirooxindole.

\section{Experimental}

Materials and Methods 
All the reagents were used without further purification and were procured from commercial sources. The reactions were performed under the normal atmosphere condition. The progress of the reaction and purity of the compound were monitored using the thin layer chromatography (TLC) carried out on the silica gel with UV light and iodine as visualizing agent. A Shimadzu FT-IR-8400 spectrophotometer was used for recording the IR spectra. ${ }^{1} \mathrm{H}$ NMR and ${ }^{13} \mathrm{C}$ NMR spectra were recorded using the Bruker advance-III $400 \mathrm{MHz}$ spectrometers in DMSO- $\mathrm{d}_{6}$ using TMS as an internal reference. The chemical shift ( $\delta$ scale) was reported in parts per million (ppm). Elemental analysis was carried out using a Euro Vector EA3000 CHNS-O analyser at NFDD Saurashtra University, Rajkot, Gujarat.

\section{General procedure for synthesis of compound 4}

A mixture of isatin (1 mmol), malononitrile $(1 \mathrm{mmol}), 4$-hydroxycoumarin $(1 \mathrm{mmol})$, and imidazole (20 mol\%) in distilled water ( $5 \mathrm{~mL}$ ) was taken in a $25 \mathrm{~mL}$ single neck round bottom flask containing magnetic bar and, under stirring, heated at $50{ }^{\circ} \mathrm{C}$ on water bath. The progress of the reaction was monitored with TLC (hexane/ethyl acetate, 7:3). After completion of the reaction it was cooled down to room temperature. The obtained solid was filtered under the suction and crystallized in methanol. The obtained filtrate containing imidazole was further used two more times, following the same procedure. The percentage of yields obtained in two different runs were found to be $87 \%$ $\left(1^{\text {st }}\right)$ and $80 \%\left(2^{\text {nd }}\right)$, respectively.

The selected spectral data for 2'-Amino-2,5'-dioxo-5'H-spiro[indoline-3,4'-pyrano[3,2-c]chromene]-3'carbonitrile (4a)

White solid, yield 95\%, $\mathrm{mp}>300{ }^{\circ} \mathrm{C}$, IR (KBr) $\left(v_{\max } / \mathrm{cm}^{-1}\right): 3358,3293,3192,3057,2208,1733$, 1610, 1473, 1352, 1171, 1092, 978, 931, and 763. ${ }^{1} \mathrm{H}$ NMR (DMSO-d $\left.6,400 \mathrm{MHz}\right): \delta 10.73(1 \mathrm{H}, \mathrm{s},-\mathrm{NH}$ ), $7.95(1 \mathrm{H}, \mathrm{d}, J=7.2 \mathrm{~Hz}, \mathrm{Ar}-\mathrm{H}), 7.82-7.75(1 \mathrm{H}, \mathrm{m}, \mathrm{Ar}-\mathrm{H}), 7.72\left(2 \mathrm{H}, \mathrm{br} \mathrm{s}, \mathrm{NH}_{2}\right), 7.55(1 \mathrm{H}, \mathrm{t}, J=7.6 \mathrm{~Hz}, \mathrm{Ar}-$ H), $7.50(1 \mathrm{H}, \mathrm{d}, J=8.4 \mathrm{~Hz}, \mathrm{Ar}-\mathrm{H}), 7.28-7.21(2 \mathrm{H}, \mathrm{m}, \mathrm{Ar}-\mathrm{H}), 6.95(1 \mathrm{H}, \mathrm{t}, J=7.6 \mathrm{~Hz}, \mathrm{Ar}-\mathrm{H}), 6.88(1 \mathrm{H}, \mathrm{d}, J=$ 8.0 Hz, Ar-H). ${ }^{13}$ C NMR (DMSO-d ${ }_{6}, 100$ MHz): $\delta$ 177.1, 158.4, 158.2, 155.0, 152.0, 142.1, 133.6, 133.0, $128.8,124.9,124.0,122.6,122.0,116.9,116.6,112.4,109.4,101.3$, 57.0, 47.5. Anal. Calcd. for $\mathrm{C}_{20} \mathrm{H}_{11} \mathrm{~N}_{3} \mathrm{O}_{4}$ : C, 67.23; $\mathrm{H}, 3.10 ; \mathrm{N}, 11.76$; found: $\mathrm{C}, 67.27 ; \mathrm{H}, 3.11 ; \mathrm{N}, 11.80$.

\section{Results and Discussion}

In our initial study, isatin (1 mmol), malononitrile $(1 \mathrm{mmol})$ and 4-hydroxycoumarin (1 mmol) were allowed to react under the catalyst-free conditions in distilled water as a solvent and at room temperature. The desired product, 4a, was obtained only in a very small amount after $24 \mathrm{~h}$ (Table 1 , 
entry 1), and slight increase in yield was observed at reflux condition in $10 \mathrm{~h}$ (Table 1, entry 2). With the same substrates combination at room temperature when imidazole $10 \mathrm{~mol} \%$ as a catalyst was added, $45 \%$ yield of the desired product was obtained (Table 1, entry 3). To our surprise, the substrates combinations in water with imidazole as catalyst when refluxed, increase in yield of 78\% was observed (Table 1, entry 4) and also reduced the reaction time to $1 \mathrm{~h}$. It was found that, both imidazole and temperature has impact on the reaction time and yield. The increase in loading of imidazole 20 mol\% significantly increased the yield to $90 \%$ of the product and reduced the reaction time (Table 1, entry 5). The reaction model with $20 \mathrm{~mol} \%$ of imidazole in water when maintained at $50{ }^{\circ} \mathrm{C}$ instead of reflux condition surprisingly, little more increase in yield was observed along with reaction time (Table 1, entry 6). Also, when catalyst loading was increased from $20 \mathrm{~mol} \%$ to $30 \mathrm{~mol} \%$ no large improvement in yield and time was observed rather yield was decreased in small amount (Table 1, entry 7). The reaction model was checked with different acid/base such as $L$-proline, TEA, DABCO and benzoic acid (Table 1, entries 8-11), but were not so efficient compared to imidazole. Finally, we have screened the model reaction with polar protic solvents such as ethanol (Table 1, entry 12) and polar aprotic solvents such as DMSO and acetonitrile (Table 1, entries 13-14), respectively, but no significant impact on yield was observed compared with that of the water solvent. Non-polar solvent such as toluene (Table 1, entry 15) was also tested in this reaction; however, the yields were found in trace amount. From the optimization, Table 1, imidazole as a catalyst and water as a solvent was observed to be the most suitable for this type of reactions.

With the optimized conditions in hand we turned our attention to explore the scope and general applicability of this process by carrying out the synthesis of spirooxindoles using different isatins and 4-hydroxycoumarin (Table 2). Isatin derivatives with varying electron donating/withdrawing functionality in the aromatic ring as well as $N$-substituted methyl/phenyl were tested and were found to be suitable in this reaction (Table 2, 4b-4g) in good yields. Highest yields were observed for $N$ protected isatin derivatives and in case of nitro derivative lower yield was observed among all the synthesized spirooxindole molecules. 6-nitro derivative of 4-hdroxycoumarin was prepared according to the reported procedure [52] and was utilized for the synthesis of $\mathbf{4 h}$ (Table 2, entry 8). These synthesized molecules were confirmed from IR spectra and melting point reported in the literature. ${ }^{1} \mathrm{H}$ NMR and ${ }^{13} \mathrm{C}$ NMR spectra for one of the compound $\mathbf{4 a}$ is provided in Figure 1 and Figure 2 , respectively.

To check the feasibility of this developed process, a scale-up reaction was performed under the optimized reaction condition to obtain 4 a by taking isatin $(10 \mathrm{mmol})$, malononitrile $(10 \mathrm{mmol})$ and 4-hydroxycoumarin (10 mmol) and the obtained yield was $97 \%$. 
Table 1. Optimization of reaction conditions ${ }^{a}$

\begin{tabular}{cccccc}
\hline & & & \\
\hline
\end{tabular}

${ }^{a}$ Reaction of isatin $(1 \mathrm{mmol})$, malononitrile $(1 \mathrm{mmol})$, 4-hydroxycoumarin $(1 \mathrm{mmol})$ at different reaction conditions

${ }^{\mathrm{b}}$ Isolated yields

Table 2. Substrates Scope ${ }^{a}$<smiles></smiles>

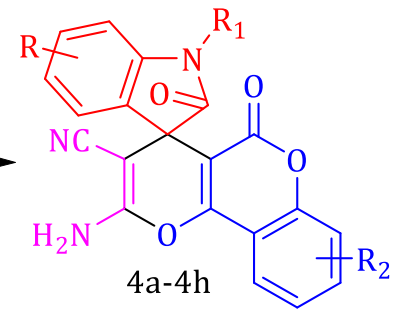

\begin{tabular}{|c|c|c|c|c|c|c|c|c|}
\hline Entry & $R$ & $\mathrm{R}_{1}$ & $\mathrm{R}_{2}$ & Product & $\begin{array}{l}\text { Time } \\
\text { (min) }\end{array}$ & $\begin{array}{l}\text { Yield }^{b} \\
(\%)\end{array}$ & Colour & M.p (oC) [Lit.] \\
\hline
\end{tabular}




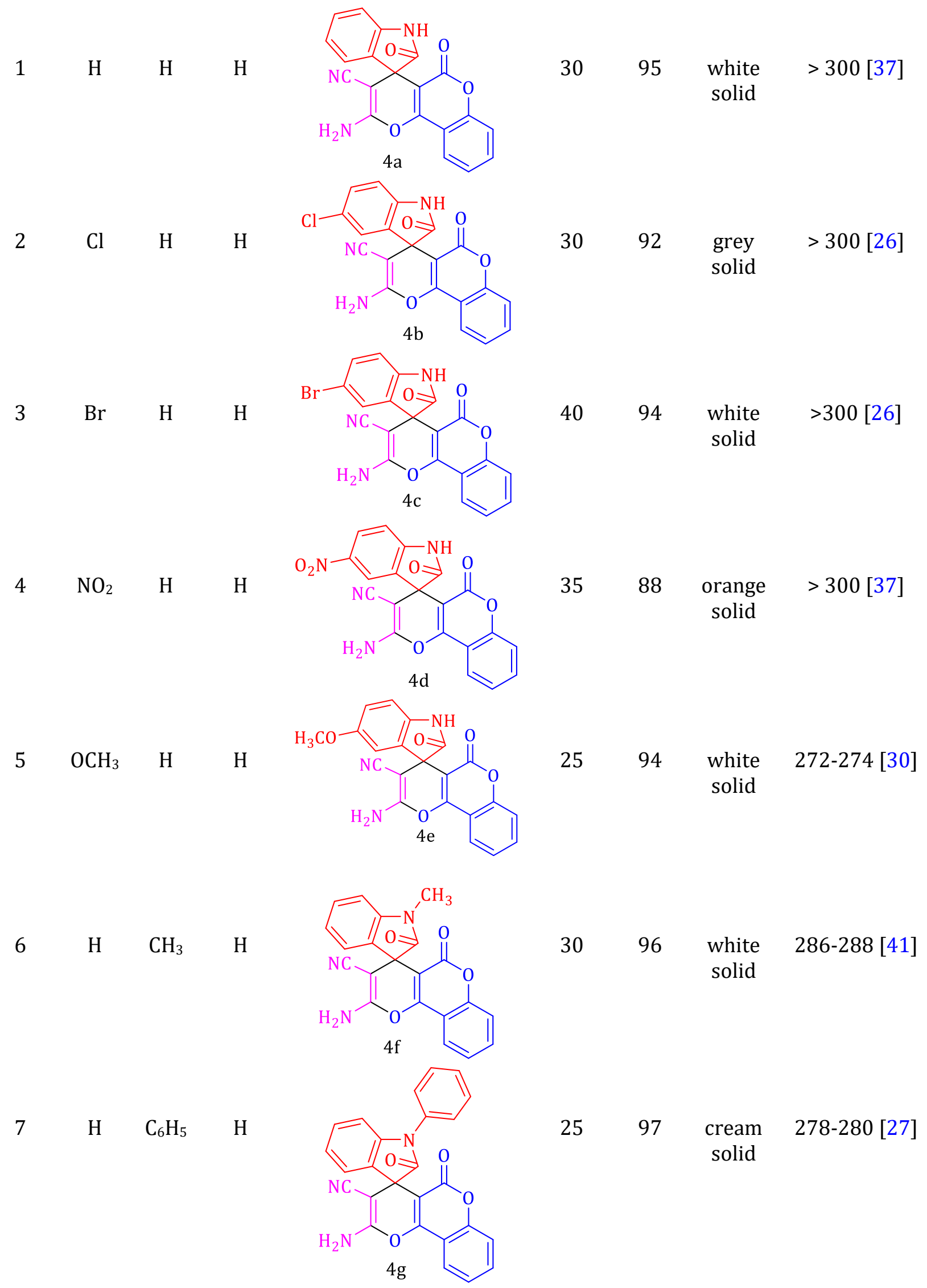




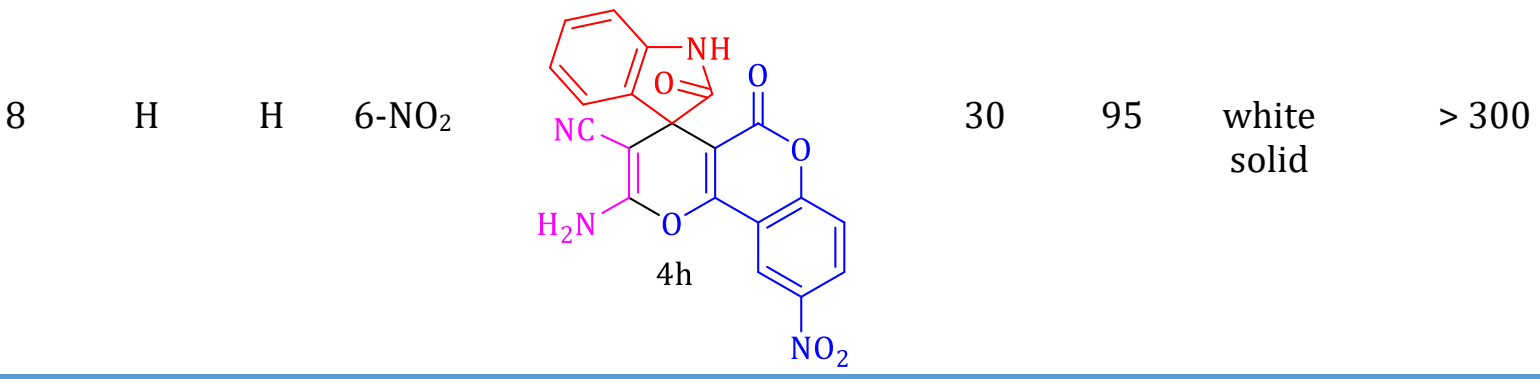

${ }^{a}$ Reaction of isatin $(1 \mathrm{mmol})$, malononitrile $(1 \mathrm{mmol})$, 4-hydroxycoumarin $(1 \mathrm{mmol})$, imidazole $(20 \mathrm{~mol} \%)$ and distilled water $(5 \mathrm{~mL})$ at $50^{\circ} \mathrm{C}$

${ }^{\mathrm{b}}$ Isolated yield

Finally, a comparison was made between the present reaction process and many other earlier reported protocols for the synthesis of $\mathbf{4 a}$ as a model compound. The results summarized in Table 3 reveals that the process developed by us is superior to most of the earlier reported methods in terms of operational simplicity, yields, reaction time, cost, easy availability, reusability, and environmental compatibility.

\section{Proposed mechanism}

In catalytic cycle of imidazole, we believed that it condenses the isatin (1) and malononitrile (2) to form an intermediate $\mathbf{A}$ (isatylidene malononitriles) which subsequently reacts

Figure 1. ${ }^{1} \mathrm{H}$ NMR spectra for $\mathbf{4 a}$

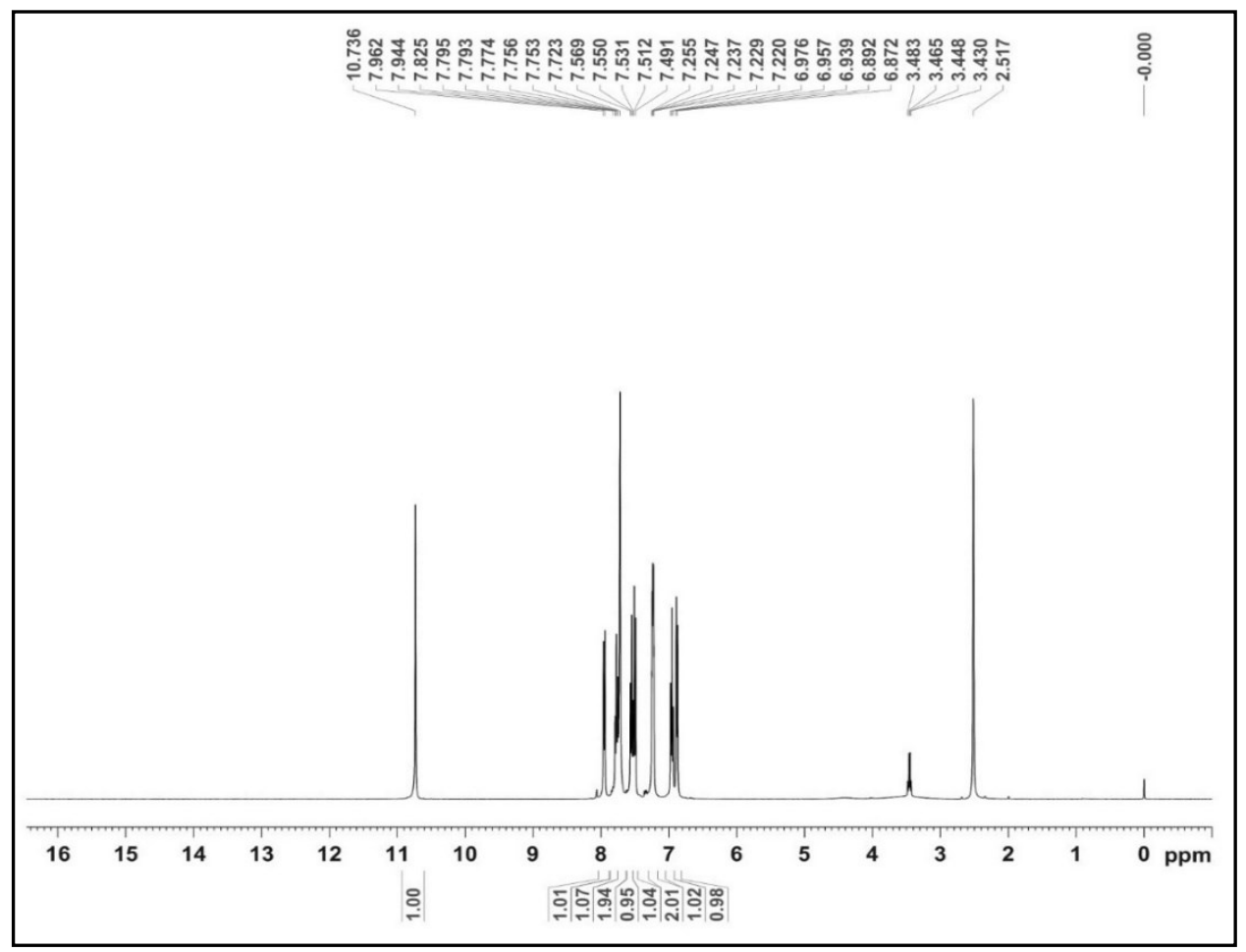




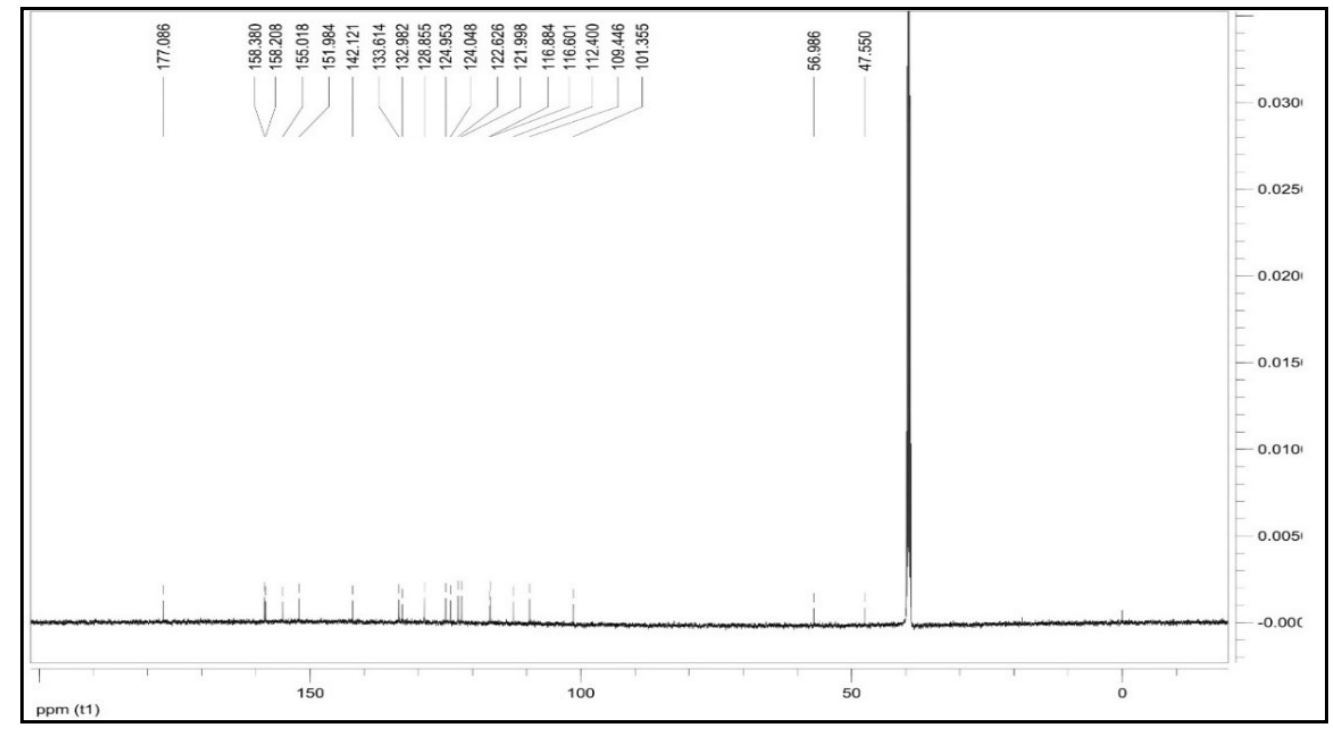

Figure $2 .{ }^{13} \mathrm{C}$ NMR spectra for $\mathbf{4 a}$

Table 3. Comparison of imidazole catalyzed synthesis of $\mathbf{4 a}$ with earlier reported protocols

\begin{tabular}{|c|c|c|c|c|c|}
\hline Entry & Catalyst & Solvent/condition & Time & Yield (\%) & Ref [Lit.] \\
\hline 1 & Borax & EtOH/Reflux & $2 \mathrm{~h}$ & 91 & 22 \\
\hline 2 & $\mathrm{Cu}(\mathrm{II})-\beta$-Cyclodextrin & EtOH/RT & $8 \mathrm{~h}$ & 80 & 23 \\
\hline 3 & $\mathrm{Fe}_{3} \mathrm{O}_{4} @ \mathrm{APTPOSS}$ a MNPs & EtOH/RT & $50 \mathrm{~min}$ & 83 & 24 \\
\hline 4 & $\mathrm{Fe}_{2} \mathrm{O}_{3}$ NPs@SiO ${ }_{2} @ v i t B_{1}$ b-NPs & $\mathrm{H}_{2} \mathrm{O} / \mathrm{US}$ & $10 \mathrm{~min}$ & 94 & 25 \\
\hline 5 & Trisodium citrate trihydrate & EtOH: $\mathrm{H}_{2} \mathrm{O}(1: 1) / \mathrm{RT}$ & $3 \mathrm{~h}$ & 92 & 26 \\
\hline 6 & $\mathrm{CuFe}_{2} \mathrm{O}_{4} \mathrm{NPs}$ & $\mathrm{EtOH} / \mathrm{H}_{2} \mathrm{O}(1: 1) /$ Reflux & $80 \mathrm{~min}$ & 85 & 27 \\
\hline 7 & $\mathrm{BN}^{c} @ \mathrm{Fe}_{3} \mathrm{O}_{4}$ & $\mathrm{H}_{2} \mathrm{O} /$ Reflux & $45 \mathrm{~min}$ & 88 & 28 \\
\hline 8 & $\mathrm{NiO}$ NPs & $\mathrm{H}_{2} \mathrm{O} / \mathrm{RT}$ & $5 \mathrm{~min}$ & 96 & 29 \\
\hline 9 & $\alpha$-Amylase (246 U) & EtOH: $\mathrm{H}_{2} \mathrm{O}(9: 1) / \mathrm{RT}$ & 2 days & 55 & 30 \\
\hline 10 & DCDBTSD $^{d}$ & $\mathrm{H}_{2} \mathrm{O} / 80{ }^{\circ} \mathrm{C}$ & $40 \mathrm{~min}$ & 95 & 31 \\
\hline 11 & {$\left[\mathrm{Ch}-\mathrm{OSO}_{3} \mathrm{H}\right]_{3} \mathrm{~W}_{12} \mathrm{PO}_{40}(\mathrm{HIL})$} & EtOH/RT & $40 \mathrm{~min}$ & 86 & 32 \\
\hline 12 & $\mathrm{EDDF}^{\mathrm{f}}$ & PEG-600/RT & $12 \min$ & 89 & 33 \\
\hline 13 & DBUg & $\mathrm{H}_{2} \mathrm{O} /$ Reflux & $10 \mathrm{~min}$ & 88 & 34 \\
\hline 14 & (Silica-bonded DBU)Cl & $\mathrm{EtOH} / \mathrm{RT}$ & $4.5 \mathrm{~h}$ & 97 & 35 \\
\hline 15 & $\mathrm{FeNi}_{3}-\mathrm{SiO}_{2} \mathrm{MNPs}$ & $\mathrm{H}_{2} \mathrm{O} / \mathrm{RT}$ & $15 \mathrm{~min}$ & 93 & 36 \\
\hline 16 & Meglumine & EtOH- $\mathrm{H}_{2} \mathrm{O}(1: 1) / \mathrm{RT}$ & 20 & 95 & 37 \\
\hline 17 & $\mathrm{SBA}^{\mathrm{h}}-\mathrm{Pr}-\mathrm{NH}_{2}$ & $\mathrm{H}_{2} \mathrm{O} /$ Reflux & $20 \min$ & 88 & 38 \\
\hline 18 & Glycerol & Glycerol/80 ${ }^{\circ} \mathrm{C}$ & $80 \min$ & 91 & 39 \\
\hline 19 & PEI@MCM-41 NPs j & Ethylene glycol, MW & $15 \min$ & 97 & 40 \\
\hline
\end{tabular}


20

21
Alum

Imidazole
$\mathrm{H}_{2} \mathrm{O}$

RT

$10 \mathrm{~h}$

85

$2 \mathrm{~h}$.

$\mathrm{H}_{2} \mathrm{O} / 50{ }^{\circ} \mathrm{C}$

$60^{\circ} \mathrm{C}$

$30 \mathrm{~min}$

92

95

\section{1}

,


with 4-hydroxycoumarin (3) to form the desired product 4 (Scheme 3). In the very first step, anion of $\mathbf{2}$ is generated by imidazole which undergoes Knoevenagel condensation with the ketone group of $\mathbf{1}$ and forms an $\alpha, \alpha$-dicyanoalkene $\mathbf{A}$. In situ generated $\mathbf{A}$ undergoes Michael addition with $\mathbf{3}$ to form another intermediate B. Further, intermediate B after keto-enol tautomerization and intramolecular condensation reaction forms the desired product 4 .

\section{Conclusion}

The present work describes an imidazole-mediated organocatalysed multicomponent reactions in water. In situ generation of isatylidene malononitriles followed by the reaction with 4hydroxycoumarin leads to easy access of a wide range of spirofused $4 \mathrm{H}$-pyrans embedded coumarin derivatives. This protocol has the advantages of a wide scope of substrates, ready availability, lower cost recyclable process, operational simplicity and there is no need for column chromatographic separation with good to high isolated yields.

\section{Acknowledgements}

Authors are grateful to the Iqra Pharmaceuticals for financial assistance to carry out this research study.

\section{Disclosure Statement}

No potential conflict of interest was reported by the authors.

\section{Orcid}

Md. Nasim Khan (iD 0000-0001-9460-3969

\section{References}

[1]. Momeni A., Samimi H., Vaezzadeh H. Chem. Methodol., 2018, 2:260

[2]. Behbahani F.K., Shahbazi R. Chem. Methodol., 2018, 2:270

[3]. Arzehgar Z., Sajjadifar S., Hossein Fekri M. Chem. Methodol., 2019, 3:251

[4]. Trabocchi A. Diversity-Oriented Synthesis: Basics and Applications in Organic Synthesis, Drug Discovery, and Chemical Biology; Wiley: Hoboken New Jersey, 2013; p 29

[5]. Zarganes-Tzitzikas T., Dömling A. Org. Chem. Front., 2014, 1:834

[6]. Weber L. Cur. Med. Chem., 2002, 9:2085

[7]. Sunderhaus J.D., Martin S.F. Chemistry, 2009, 15:1300

[8]. Kaur M., Singh M., Chadha N., Silakari O. Eur. J. Med. Chem., 2016, 123:858 
[9]. Ye N., Chen H., Wold E.A., Shi P.Y., Zhou J. ACS Infect. Dis., 2016, 2:382

[10]. Yu B., Yu D.Q., Liu H.M. Eur. J. Med. Chem., 2015, 97:673

[11]. Sun Y., Liu J., Jiang X., Sun T., Liu L., Zhang X., Ding S., Li J., Zhuang Y., Wang Y., Wang R. Sci. Rep., 2015, 5:13699

[12]. Baran P.S., Richter J.M. J. Am. Chem. Soc., 2005, 127:15394

[13]. Edmondson S., Danishefsky S.J., Sepp-Lorenzino L., Rosen N. J. Am. Chem. Soc., 1999, 121:2147

[14]. Saraswat P., Jeyabalan G., Hassan M.Z., Rahman M.U., Nyola N.K. Synth. Commun., 2016, 46:1643

[15]. Panda S.S., Jones R.A., Bachawala P., Mohapatra P.P. Mini Rev. Med. Chem., 2017, 17:1515

[16]. Zheng Y.J., Tice C.M. Expert Opin. Drug Discov. 2016, 11:831

[17]. Wang S., Sun W., Zhao Y., McEachern D., Meaux I., Barriere C., Stuckey J.A., Meagher J.L., Bai L., Liu L., Hoffman-Luca C.G., Lu J., Shangary S., Yu S., Bernard D., Aguilar A., Dos-Santos O., Besret L., Guerif S., Pannier P., Gorge-Bernat D., Debussche L. Cancer Res., 2014, 74:5855

[18]. Singh G.S., Desta Z.Y. Chem. Rev., 2012, 112:6104

[19]. Pal S., Khan M.N., Karamthulla S., Choudhury L.H. Tetrahedron Lett., 2015, 56:359

[20]. Pal S., Khan M.N., Karamthulla S., Abbas S.J., Choudhury L.H. Tetrahedron Lett., 2013, 54:5434

[21]. Karamthulla S., Pal S., Khan M.N., Choudhury L.H. RSC Adv., 2013, 13:15576

[22]. Molla A., Ranjan S., Rao M.S., Dar A.H., Shyam M., Jayaprakash V., Hussain S. ChemistrySelect, 2018, 3:8669

[23]. Sadat-Ebrahimi S.E., Haghayegh-Zavareh S.M., Bahadorikhalili S., Yahya-Meymandi A., Mahdavi M., Saeedi M. Synth. Commun., 2017, 47:2324

[24]. Safaei-Ghomi J., Nazemzadeh S. H., Shahbazi-Alavi H. Catal. Commun., 2016, 86:14

[25]. Singh N.G., Lily M., Devi S.P., Rahman N., Ahmed A., Chandra A.K., Nongkhlaw R. Green Chem., 2016, 18:4216

[26]. Brahmachari G., Banerjee B. Asian J. Org. Chem., 2016, 5:271

[27]. Baghernejad M., Khodabakhshi S., Tajik S. New J. Chem., 2016, 40:2704

[28]. Molla A., Hussain S. RSC Adv., 2016, 6:5491

[29]. Nasseri M.A., Kamali F., Zakerinasab B. RSC Adv., 2015, 5:26517

[30]. He T., Zeng Q.Q., Yang D.C., He Y.H., Guan Z. RSC Adv., 2015, 5:37843

[31]. Khazaei A., Zolfigol M. A., Karimitabar F., Nikokar I., Moosavi-Zarec A. R. RSC Adv., 2015, 5:71402

[32]. Satasia S.P., Kalaria P.N., Avalani J.R., Raval D.K. Tetrahedron, 2014, 70:5763

[33]. Thakur A., Tripathi M., Rajesh U.C., Rawat D.S. RSC Adv., 2013, 3:18142

[34]. Saluja P., Aggarwal K., Khurana J.M. Synth. Commun., 2013, 43:3239

[35]. Hasaninejad A., Golzar N., Beyrati M., Zare A., Doroodmand M.M. J. Mol. Catal. A Chem., 2013, 372:137 
[36]. Nasseri M.A., Sadeghzadeh S.M. J. Iran Chem. Soc., 2013, 10:1047

[37]. Guo R.Y., An Z.M., Mo L.P., Wang R.Z., Liu H.X., Wang S.X., Zhang Z.H. ACS Comb. Sci., 2013, 15:557

[38]. Mohammadi Ziarani G., Hosseini Mohtasham N., Lashgari N., Badiei A., Amanlou M., Bazlc R. J. Nanostruct., 2013, 2:489

[39]. Safaei H.R., Shekouhy M., Rahmanpur S., Shirinfeshan A. Green Chem., 2012, 14:1696

[40]. Hamadi H., Gholami M., Khoobi M. International J. Heterocyclic Chem., 2011, 1:1

[41]. Karimi A.R., Sedaghatpour F. Synthesis, 2010, 10:1731

[42]. Baer D.R., Munusamy P., Thrall B.D. Biointerphases, 2016, 11:04B401

[43]. Karakoti A.S., Munusamy P., Hostetler K., Kodali V., Kuchibhatla S., Orr G., Pounds J.G., Teeguarden J.G., Thrall B.D., Baer D.R. Surf. Interface Anal., 2012, 44:882

[44]. Baer D.R. Front. Chem., 2018, 6:145

[45]. Bertelsen S., Jorgensen K.A. Chem. Soc. Rev., 2009, 38:2178

[46]. Dalpozzo R., Bartoli G., Bencivenni G., Chem. Soc. Rev., 2012, 41:7247

[47]. Qin Y., Zhu L., Luo S. Chem. Rev., 2017, 117:9433

[48]. Verma S.K., Acharya B.N., Kaushik M.P. Org. Lett., 2010, 12:4232

[49]. Huang X.G., Liu J., Ren J., Wang T., Chen W., Zeng B.B. Tetrahedron., 2011, 67:6202

[50]. Guan X.Y., Shi M. Org. Biomol. Chem., 2008, 6:3616

[51]. Khan M.N., Pal S., Karamthulla S., Choudhury L.H. RSC Adv., 2013, 4:3732

[52]. Huang C.N., Kuo P.Y., Lin C.H., Yang D.Y. Tetrahedron, 2007, 63:10025

How to cite this manuscript: Md. Nasim Khan*, Digvijaysinh K. Parmar, Hardik B. Bhatt. Imidazole mediated synthesis of spirooxindoles in water using isatin as a privileged scaffold . Asian Journal of Green Chemistry, 3(4) 2019, 470-482. DOI: 10.33945/SAMI/AJGC.2019.4.4 